UDC: $378.016:[54+004]+159.9$

DOI: https://doi.org/10.24195/2414-4665-2017-6-8

\author{
Tetiana Derkach, \\ Doctor of Pedagogy, associate professor, \\ Department of Industrial Pharmacy, \\ Kyiv National University of Technologies and Design, \\ 2, Nemyrovycha-Danchenka Str., Kyiv, Ukraine, \\ Tetiana Starova, \\ PhD (Candidate of Chemical Sciences), \\ head of the Department of Chemistry and Chemistry Teaching Methods, \\ Kryvyi Rih State Pedagogical University, \\ 54, Haharina Avenue, Kryvyi Rih, Ukraine
}

\title{
PREFERRED LEARNING STYLES OF STUDENTS OF NATURAL FIELD OF STUDY
}

Indexes of learning styles of students majoring in "Biology and Chemistry" and "Chemistry and Informatics" were assessed by Felder-Soloman's Index of Learning Styles. The respondents of both specialties demonstrate a pronounced active style of information processing and sensitive style of perception. They preferably use visual sensors for information perception. The difference between the specialties under comparison consists in learning patterns. The respondents majoring in "Biology and Chemistry" demonstrate preferred sequential style of understanding while the students majoring in "Chemistry and Informatics" are characterized by a balance between sequential and global styles. The characteristics of the preferred learning styles obtained in the experiment mainly conform to those of students of natural science and computer specialties at universities of the world.

Keywords: higher education, Felder-Soloman Index of Learning Style, students majoring in natural and computer science.

\section{Introduction}

The arrangement of conditions for effective learning is now becoming ever more urgent because onrush of information and communication technologies dramatically changes the modern educational environment. First of all, this concerns the use of electronic learning resources. The scientists in this field have been paying special attention to students' learning styles (LSs) as well as to coordination between learning and teaching styles [1-4].

Researchers have been studying students' LSs for a long time and have already distinguished a lot of LSs models. Those of them that consider LSs as an integrated formation are characterized by a greater explanatory power. However, many issues still remain unresolved. It has not been clear so far whether LSs are personality traits and thereby are stable and invariable, or they are mental states and thus can change [5]. Another question, which is related to any long-term changes of LSs as a function of age, sex, academic disciplines, extracurricular activities, etc., also remains open. Modern scientific literature provides insufficient amount of information about possibilities of improving learning efficiency in various fields of study by means of intentional formation of particular LS in students [6]. The findings of different authors often contradict one another [7;8].

Students majoring in different specialties differ in their preferred LSs but the reason for this is not clear yet [9; 10]. Scientists readily describe such differences but rarely consider them in dynamics, in correlation with the progress in learning or in connection with the efficiency of the teaching methods used. Obviously, such discrepancies illustrate the complexity of the problem and require further research in this area.

The paper aims to analyze the preferred learning styles of students of different specialties.

\section{Research methods}

The study of preferred LSs was performed at the Faculty of Natural Sciences of Kryvyi Rih State Pedagogical University (KSPU) in Ukraine. Learning styles were investigated for first- to third-year students majoring in "Biology" with "Chemistry" as an additional specialty (hereinafter $\mathrm{B} \& \mathrm{Ch}$ ) and for first- to fifth-year students majoring in "Chemistry" with "Informatics" as the additional specialty (Ch\&I). The training of students in these fields differs in the contents of modules, the volumes of credits and in the variable part of the curriculum. Thus, the variable part of Ch\&I includes disciplines of specialty "Informatics" in the amount of 38 credits, while that of $\mathrm{B} \& \mathrm{Ch}$ contains 52 credits for disciplines of specialty "Chemistry".

Felder-Soloman's Index of Learning Styles (ILS) [11] was used to find the LSs. The method helps to assess preferences on four complementary dimensions (Table 1). ILS categorizes individuals' preferences in terms of a type and a mode of information perception, approaches to the information processing and the progress rate towards understanding. The results obtained allow one to determine fractions of respondents $\left(F_{i}\right)$ which demonstrate preferences to certain LSs for each dimension. 
Dimensions of Felder-Soloman method

Table 1.

\begin{tabular}{|l|l|l|l|}
\hline \multirow{2}{*}{ Dimension } & Types & \multirow{2}{*}{} & \multirow{2}{*}{ Description } \\
\cline { 2 - 4 } & Name & Abbr. & \\
\hline \multirow{2}{*}{ Perception } & Sensitive & sen & Concrete thinkers, focused on facts and procedures \\
\cline { 2 - 4 } & Intuitive & int & Abstract thinkers, focused on theories and meanings \\
\hline \multirow{2}{*}{ Input } & Visual & vis & Prefer visual representations \\
\cline { 2 - 4 } & Verbal & vrb & Prefer written and spoken explanations \\
\hline \multirow{2}{*}{ Processing } & Active & act & Learn by trying things out, enjoy working in groups \\
\cline { 2 - 4 } & Reflective & ref & Learn by thinking things through, prefer working alone \\
\hline \multirow{2}{*}{ Understanding } & Sequential & seq & Linear thinking process, learn in small incremental steps \\
\cline { 2 - 4 } & Global & glo & Holistic thinking process, learn in large leaps \\
\hline
\end{tabular}
lows:

The fractions of preferred LS were calculated as fol-

$$
F_{\mathrm{i}}=N_{\mathrm{i}} / N
$$

where $N_{i}$ and $N$ are the number of students with preferred LS $i$ and the total number of participated students, respectively.

In addition to the experimental results obtained, available literature data on the application of Felder-
Soloman method were analyzed to study preferred styles of students of various branches of knowledge and countries. The methods of data processing and sources used were described in detail in our previous works $[1,7]$.

\section{Results and Discussion}

The values of $F_{i}$ are shown in Table 2 for LSs act, sen, vis and seq.

Number of students (N) of each specialty at the Faculty of Natural Sciences of KSPU with their fractions $\left(F_{i}, \%\right)$ of act, sen, vis and seq LSs

\begin{tabular}{|l|l|l|l|l|l|l|}
\hline Specialty & \multirow{2}{*}{ Years } & \multirow{2}{*}{$N$} & \multicolumn{4}{|c|}{$F_{i}, \%$} \\
\cline { 4 - 7 } & & & act & sen & vis & seq \\
\hline B\&Ch & $1-3$ & 37 & 62.2 & 70.3 & 70.3 & 64.9 \\
\hline Ch\&I & $1-5$ & 52 & 80.8 & 82.7 & 75.0 & 51.9 \\
\hline Ch\&I & 1 & 14 & 85.7 & 78.6 & 71.4 & 42.9 \\
\hline Ch\&I & $3-5$ & 31 & 77.4 & 83.9 & 80.6 & 58.1 \\
\hline Total $N$ and average $F_{i}$ & & 89 & 73.0 & 77.5 & 73.0 & 57.3 \\
\hline
\end{tabular}

The students' fractions with different preferences are shown in Fig. 1 for all four dimensions. Both specialties show similar behavior which is characterized by marked preferences $\left(F_{i}>50 \%\right)$ in favor of styles act, sen and vis.

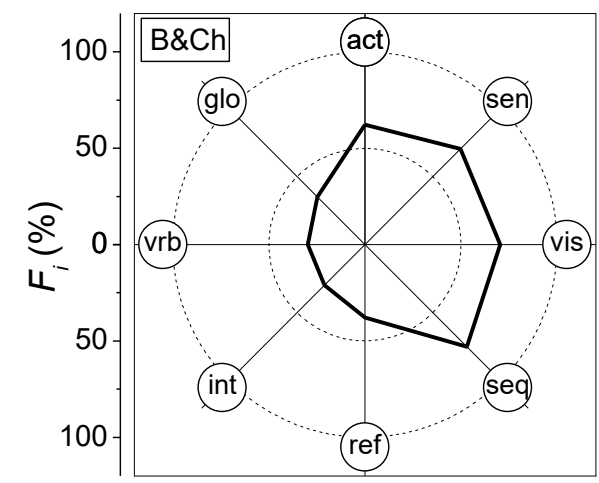

Table 2.

As for seq-glo dimension, B\&Ch specialty is characterized by a preferred seq style while both $F_{\text {seq }}$ and $F_{\text {glo }}$ values are close to the equilibrium point, i.e. $50 \%$, for Ch\&I specialty.

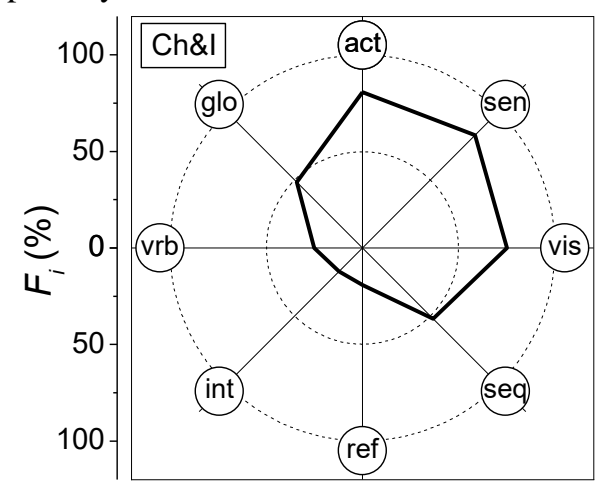

Fig. 1. Fractions $F_{i}(\%)$ of preferred LSs by students of B\&Ch and Ch\&I specialties

The results obtained raise at least two questions, the answers to which are essential for optimizing the learning process. First, does the observed difference between specialties in students' preferences reflect general patterns rather than it is a feature of the investigated sample? Sec- ond, if the invented differences in LSs have fundamental grounds, what are the reasons for such a phenomenon?

We turn to the literature data for learning preferences of students of different fields of study to answer the first question. The literature data used were summarized in [7] and supplemented with the results of our previous works 
[12]. The average characteristics of preferred LSs based on the surveys of 9258 students (incl. 3279 first-year students) from 35 universities of 15 countries $[1 ; 7 ; 12]$ were compared with those of KDPU students (Table 2) and are presented in Fig. 2.
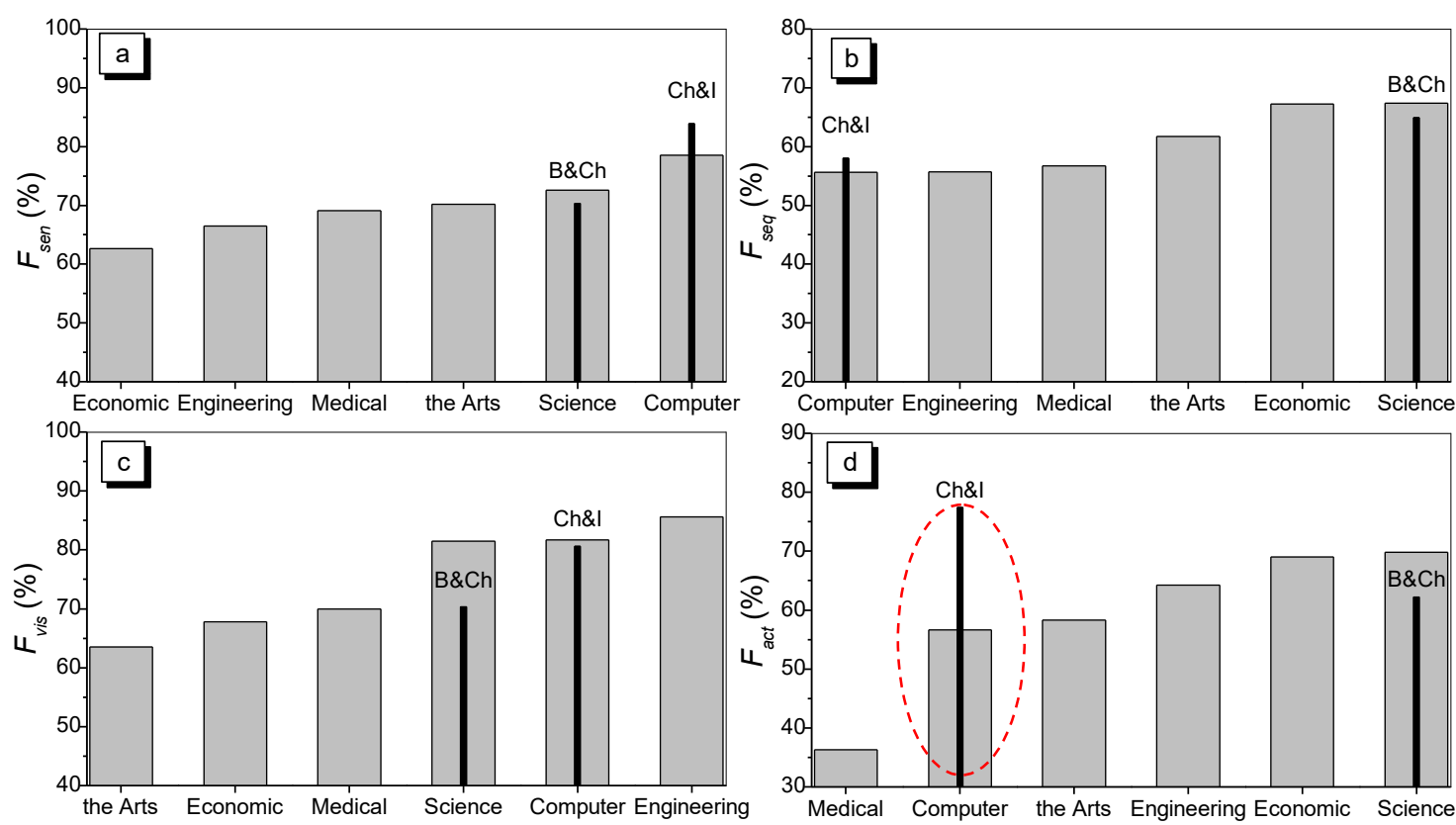

Fig. 2 Students' fractions $F_{i}(\%)$ for LSs sen (a), seq (b), vis (c) and act (d) vs field of study at world universities compared to $B \& C h$ and $C h \& I$ specialties

The curriculum of Ch\&I students includes 38 credits for computer science, including programming languages and computer simulation. Similar disciplines but in larger amounts are included in the curricula of Bachelors with the main field of study "Informatics". This gives us some reasons to compare LSs of Ch\&I students with those of computer fields of study. On the other hand, the training of $\mathrm{B} \& \mathrm{Ch}$ students is typical for specialties of natural science. Therefore, students' LSs for this specialty can be compared with those for natural science students.

As seen from Fig. 2a, the greatest advantage of sen style over int style is typical for students of both computer and natural sciences. The indicators of KSPU students well conform with the world indices. On the contrary, the advantage of sen over int style is minimal for economic science and engineering.

The world and KSPU results are similar in terms of seq style (Fig. 2b). The students of natural science and B\&Ch specialty demonstrate the highest values of $F_{\text {seq }}$. The figures for students of computer science and $\mathrm{B} \& \mathrm{Ch}$ are located on the opposite side of the diagram and their values of $F_{\text {seq }}$ and $F_{\text {glo }}$ are close to $50 \%$.

For vis-vrb dimension (Fig. 2c), engineering, computer and natural sciences are characterized by a pronounced advantage of vis style. The indices demonstrated by KDPU students are generally similar to the world indices. The values of $F_{v i s}$ for Ch\&I and for B\&Ch are only by $9 \%$ and $15 \%$ lower than those for computer and natural sciences respectively. The advantage of vis over vrb style is minimal for the arts and economic fields of studies.

The results of B\&Ch students $\left(F_{a c t}=62.2 \%\right)$ for actref dimension correlate with the world index $\left(F_{a c t}=62.2 \%\right)$ that corresponds to a moderate advantage of act style over ref style (Fig. 2d). The most serious contradiction is observed between Ch\&I specialty and computer field of study. While the value of $F_{a c t}$ for Ch\&I specialty corresponds to an evident advantage of active style, a balance between act and ref styles is typical for students of computer science.

The Ch\&I specialty has 38 credits for computer disciplines. Some of them, such as "Computer statistical analysis of the results of chemical experiments", "Computer modelling of chemical processes" and "Computer mathematics in chemistry", are strongly integrated with chemical subjects. They are in fact applied software packages aimed at the solving chemical tasks. Thus, a high degree of integration with natural science is typical for Ch\&I specialty and, perhaps, this causes some discrepancy with students of pure informatics major in preferred LSs.

The reasons of difference in preferred LSs between different specialties have not been completely clarified yet. We distinguish two possible ones:

1) Certain LSs make a perfect match with some fields of study but they do not harmonize with other sciences. This is caused by discipline contents, teaching methods, etc. Students with LSs formed in previous years 
often make subconscious choice of a field of study which will benefit their LSs better than other specialties.

2) Learning styles are flexible. They are influenced by discipline content and teaching methods and can be changed in the course of study.

A permanent monitoring of preferred LSs for a rather large number of respondents during a few years of study can provide the most precise answer to this question. However, some preliminary information can be obtained if preferred LSs of the first-year students are compared with those of senior students. The effect of content and methods of learning is minimal for the first-year students. Therefore, in most cases their LSs were formed before the start of study. The coefficient $\Delta F_{i}$ can be used as a measure of time variability of LS $i$ and is calculated as follows:

$$
\Delta F_{\mathrm{i}}=100 \% \times \frac{2\left(F_{\mathrm{i}}^{s}-F_{i}^{f}\right)}{F_{\mathrm{i}}^{s}+F_{\mathrm{i}}^{f}},
$$

where $F_{i}^{g}$ and $F_{i}^{f}$ are the fractions of preferred styles for senior students (superscript s) and freshmen (superscript $f$ ) respectively defined by formulae (1).

The relative changes in LSs of senior students compared to those of first-year students are shown in Fig. 3. The values of $\Delta F_{i}$ are illustrated for both computer science students of world universities (totally 92 senior and 130 first-year students were surveyed) and Ch\&I students (31 third- to fifth year and 14 first-year students as shown in Table 2). The directions of changes in LSs are identical for both data sets. The number of students with active LS decreases with time and simultaneously the numbers of students with sensitive, visual and sequential styles increase. Average world learning preferences do not qualitatively change in three dimensions. In going from first to senior years, the senior students are still more visual and sensitive in information perception in spite of some changes in their $F_{i}$ values. A balance between seq and glo styles also holds true. Nevertheless, initial advantage of act style over ref style which is typical for freshmen shifts to act-ref equilibrium for senior students.

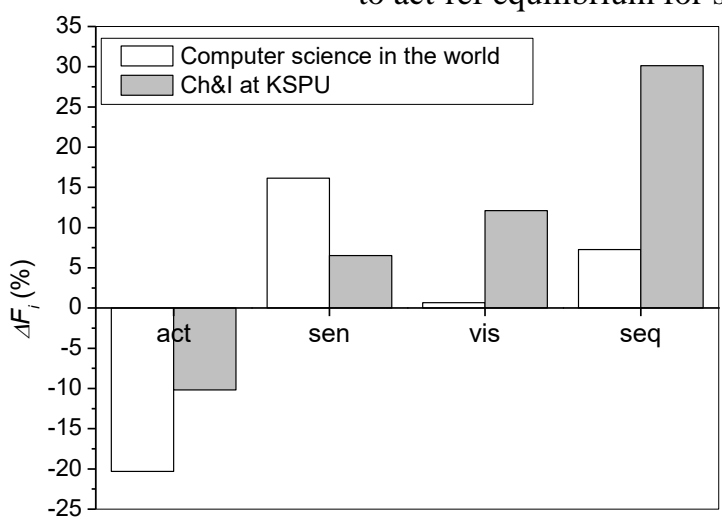

Fig. 3 Variability coefficients $\Delta F_{i}$ for preferred LSs (act, sen, vis and seq): Computer science students in the world are compared with Ch\&I students

The learning preferences of KSPU students are not radically changed with years of study. Actual, sensitive, visual and sequential styles still dominate over their counterparts. The only noticeable changes concern a seq-glo pair. The $F_{g e n}^{f}$ value for freshmen is equal to $43 \%$, while $F_{g e n}^{g}=58 \%$ for senior students. However, both results are within a 40-60\% range, i.e. around equilibrium $50 \%$.

\section{Conclusions}

1. ILSs were calculated with the use of FelderSoloman method for 89 students of natural science field at the Faculty of Natural Sciences of KSPU.

2. Students of "Biology and Chemistry" specialty predominantly demonstrate active and sensitive styles in information processing and perception, prefer visual representations of presented materials and are in favour of convergent thinking and analysis (sequential style) in the process of learning.

\section{REFERENCES}

1. Derkach, T. M. (2013). Teoretychni ta metodychni osnovy pidhotovky maibutnikh fakhivtsiv khimichnykh
3. Students of "Chemistry and Informatics" specialty have similar preferences with respect to active, sensitive and visual styles. However, there is a balance between sequential and global styles.

4. The results of the survey were compared with the published ILS for students of various fields of study at universities of the world. The preferred styles of "Biology and Chemistry" specialty were shown to correlate with those of natural science students. Correlations between "Chemistry and Informatics" specialty and computer science students are observed for 3 of 4 dimensions. Some discrepancy concerns active-reflective dimension. Computer science students are well balanced while the students surveyed in the given research are more disposed to active style. 
ing of future specialists of chemical specialties by means of information technologies: monograph]. Donetsk: ARTPRES [in Ukrainian].

2. Derkach, T. M. (2012). Spryiniattia elektronnykh navchalnykh resursiv studentamy $\mathrm{z}$ riznymy styliamy navchannia [Perception of e-learning resources by students with different learning styles]. Naukovi Zapysky: Zb. nauk. statei NPU im. M. P. Drahomanova. - Scientific notes. Collection of scientific works. Kyiv: Vyd-vo NPU im. M.P. Drahomanova, 100, 87-97 [in Ukrainian].

3. Truong, H.M. (2016). Integrating learning styles and adaptive e-learning system: Current developments, problems and opportunities. Computers in Human Behavior, 55, 1185-1193 [in English].

4. Derkach, T.M. (2016). Electronic resources in teaching basic chemical disciplines at universities. Nauka $i$ osvita - Science and education, 12, 99-109 [in English].

5. Berg, H. van den. (2015). Changes in learning styles induced by practical training. Learning and Individual Differences, 40, 84-89 [in English].

6. Polat, Y., \& Peker, A. A., \& Özpeynirci, R., \& Duman, H. (2015). The effect of learning styles of accounting education students on their performance: a field study. Procedia - Social and Behavioral Sciences, 174 ,

$1841-1848$

[in English].

7. Yaroshenko, O. H. \& Derkach T. M. (2012). Porivnialnyi analiz styliv navchannia studentiv riznykh

\section{ЛІТЕРАТУРА}

1. Деркач Т. М. Теоретичні та методичні основи підготовки майбутніх фахівців хімічних спеціальностей засобами інформаційних технологій : моногр. / Т. М. Деркач. - Д. : АРТ-ПРЕС, 2013. - 320 с.

2. Деркач Т. М. Сприйняття електронних навчальних ресурсів студентами 3 різними стилями навчання / Т. М. Деркач // Наукові записки: Зб. наук. статей НПУ ім. М. П. Драгоманова. - К. : Вид-во НПУ ім. М. П. Драгоманова. - 2012. - № 100. - С. 87-97.

3. Truon H. M. Integrating learning styles and adaptive e-learning system: Current developments, problems and opportunities / H. M. Truon // Computers in Human Behavior. - 2016. - V. 55. -P. 1185-1193.

4. Derkach T. M. Electronic resources in teaching basic chemical disciplines at universities / T. M. Derkach // Наука і освіта. - 2016. - № 12. - С.99-109.

5. Berg H. van den. Changes in learning styles induced by practical training / H. van den Berg // Learning \& Individual Differences. - 2015. - V. 40. - P. 84-89.

6. Polat Y. The effect of learning styles of accounting education students on their performance: a field study / Y. Polat, A.A. Peker, R. Özpeynirci, H. Duman // Procedia - Social and Behavioral Sciences. - 2015. V. 174. - P. 1841-1848.

7. Ярошенко О. Г. Порівняльний аналіз стилів навчання студентів різних спеціальностей / spetsialnostei [Comparative analysis of learning styles for students of different specialties]. Pedahohika $i$ psykholohiia - Pedagogics and Psychology, 1, 43-47 [in Ukrainian].

8. Maric, M. \& Penger, S. \& Todorovic, I. \& Djuric, N. \& Pintar, R. (2015). Differences in Learning Styles: A comparison of Slovenian Universities. Procedia - Social and Behavioral Sciences, 197, 175-183 [in English].

9. Tulbure, C. (2012). Learning styles, teaching strategies and academic achievement in higher education: A cross-sectional investigation. Procedia - Social and Behavioral Science, 33, 398-402 [in English].

10. Dincol, S. \& Temel, S. \& Oskay, Ö.Ö. \& Erdogan, Ü.I. \& Yilmaz A. (2011). The effect of matching learning styles with teaching styles on success. Procedia Social and Behavioral Sciences, 15, 854-858 [in English].

11. Sait of "Index of learning styles (ILS)". Retried from:

http://www4.ncsu.edu/unity/lockers/users/f/felder/public/I LSpage.html [in English].

12. Derkach, T. M. (2011). Vplyv okremykh aspektiv styliv navchannia na zasvoiennia studentamy khimichnykh znan [The effect of individual aspects of learning styles on the acquisition of chemical knowledge by students]. Pedahohika i psykholohiia profesiinoi osvity - Pedagogy and Psychology of Professional Educatio, 5, 33-41 [in Ukrainian].

О. Г. Ярошенко Т. М. Деркач // Педагогіка і психологія. - 2012. - № 1. - С. 43-47.

8. Maric M. Differences in Learning Styles: A comparison of Slovenian Universities / M. Maric, S. Penger, I. Todorovic, N. Djuric, R. Pintar // Procedia - Social and Behavioral Sciences. - 2015. - V. 197. - P. 175-183.

9. Tulbure C. Learning styles, teaching strategies and academic achievement in higher education: A crosssectional investigation / C. Tulbure // Procedia - Social and Behavioral Sciences. - 2012. - V. 33. P. 398-402.

10. Dincol S. The effect of matching learning styles with teaching styles on success / S. Dincol, S. Temel, Ö. Ö. Oskay, Ü. I. Erdogan, A. Yilmaz // Procedia - Social and Behavioral Sciences. - 2011. - V. 15. - P. 854858.

11. Felder R.M. Index of learning styles (ILS). [Електронний pecypc] / R.M. Felder. - Режим доступу 19.08.2011:// http://www4.ncsu.edu/unity/lockers/ users/f/felder/public/ILSpage.html. - Заг. 3 екрана. Мова англ.

12. Деркач Т. М. Вплив окремих аспектів стилів навчання на засвоєння студентами хімічних знань/ Т. М. Деркач // Педагогіка і психологія професійної освіти. - 2011. - № 5. - С. 33-41. 
Тетяна Михайлівна Деркач, доктор педагогічних наук, доцент кафедри промислової фармації, Київський національний університет технологій та дизайну, вул. Немировича-Данченка, 2, м. Київ, 01011, Україна

Тетяна Валерї̈вна Старова, кандидат хімічних наук, завідувач кафедри хімї та методики ї̈ навчання, Криворізький державний педагогічний університет, пр. Гагаріна, 54, м. Кривий Ріг, 50086, Украӥна

ПЕРЕВАЖАЮЧІ СТИЛІ НАВЧАННЯ СТУДЕНТІВ ПРИРОДНИЧОГО НАПРЯМУ ПІДГОТОВКИ

3'ясування ролі сформованих у студентів стилів навчання та можливого «конфлікту» стилів навчання та викладання є важливим та актуальним питанням. Складність проблеми полягає в тому, що відмінності студентів, характерні для підготовки конкретних спеціальностей, рідко розглядаються у динаміці, кореляції з успішністю у навчанні та у зв'язку із ефективністю методики викладання. Метою роботи $є$ аналіз навчальних переваг студентів різних спеціальностей на базі результатів власного експерименту та літературних даних. Дослідження здійснено на базі природничого факультету Криворізького державного педагогічного університету. Методом Фелдера-Соломан визначено індекси стилів навчання у студентів напрямів підготовки «біологія і хімія» та «хімія і інформатика». Метод розподіляє респондентів за чотирьма вимірами згідно з їхніми перевагами у існуючих типах сприйняття та обробки інформації, темпах прогресу у їі опануванні. Підготовка студентів названих напрямів відрізнялась змістом модулів варіативної частини навчальних планів. Для напряму «хімія і інформатика» вона включала інформатичні дисципліни обсягом 38 кредитів, а для спеціальності «біологія і хімія»хімічні дисципліни обсягом 52 кредити. Студенти обох спеціальностей демонструють виражений активний стиль опанування та сенситивний стиль усвідомлення інформації, а також використовують переважно візуальний сенсор для її сприйняття. Студентів «біології та хімії» характеризує перевага послідовного стилю. Для спеціальності «хімія та інформатика» спостерігається рівновага між послідовним та глобальним стилями. Також проаналізовано літературні дані щодо застосування методу для визначення стилів навчання у студентів різних країн та напрямів підготовки. Результати опитування 9258 студентів з 35 університетів 15 країн світу порівнювали $з$ результатами опитування студентів КДПУ. Експериментальні дані за більшістю позицій узгоджуються 3 наявними в літературі. Так, показники навчальних переваг студентів напряму «біологія і хімія» корелюють 3 перевагами студентів природничих спеціальностей. Кореляцію між показниками студентів «хімії і інформатики» та узагальненими даними щодо студентів комп'ютерних спеціальностей зафіксовано за 3-х вимірами із 4-х.

Ключові слова: вища освіта, індекси стилів навчання Фелдера-Соломан, студенти природничих та комп'ютерних спеціальностей.

Submitted on May, 19, 2017 